\title{
Communication Strategy of Content Collision Agency in Promoting the Blibli.com Brand
}

\author{
William Ardo Nofrizal \\ Communication Studies, Faculty of Creative Industries, Institut Teknologi dan Bisnis Kalbis \\ Jalan Pulomas Selatan Kav. 22, East Jakarta, Indonesia \\ williamnovry@gmail.com \\ Santi Delliana* \\ Communication Studies, Faculty of Creative Industries, Institut Teknologi dan Bisnis Kalbis \\ Jalan Pulomas Selatan Kav. 22, East Jakarta, Indonesia \\ anastasia.santi@kalbis.ac.id
}

Received: 06-02-2021

Accepted: 16-06-2021

Published: 30-06-2021

\begin{abstract}
ABSTRAK
Era digital telah menyebabkan munculnya banyak perusahaan seperti E-commerce yang proses pemasarannya tidak hanya melakukan pemasaran melalui media offline tetapi juga telah merambah media onlineldigital. BliBli.com mempromosikan brandnya bekerja sama dengan agensi digital Content Collision untuk dapat memberikan SEO (Search Engine Optimization) yang meningkatkan PageRank di Google. Tujuan dari penelitian ini adalah mengetahui bagaimana strategi komunikasi yang dilakukan oleh Content Collision Agency. Metode penelitian yang digunakan adalah pengumpulan data deskriptif kualitatif melalui wawancara, observasi, dan studi dokumen. Hasil penelitian menunjukkan bahwa strategi komunikasi yang digunakan Content Collision Agency dalam mempromosikan BliBli.com adalah dengan mengelola blog BliBli.com agar lebih menarik. Konten yang terdapat pada website berupa artikel, slideshare, infografik, dan live report di lapangan, diberikan call to action pada setiap dokumen yang telah dibuat. Kontennya SEO friendly, up to date, kreatif, informatif, menghibur, didistribusikan melalui media online, dan disertai backlink seperti $Q R$ code dan tombol aksi (beli sekarang). Cara ini memudahkan pembaca untuk bisa mendapatkan produk dan promosi yang tersedia di Blibli.com. Pembaca juga dapat berbagi dengan mengklik share yang berfungsi sebagai ungkapan mengekspresikan suka artikel dan ingin berbagi informasi dengan orang lain atau sekedar memberikan umpan balik untuk konten melalui komentar. Review produk/jasa dari brand meningkatkan jumlah view dan penjualan.
\end{abstract}

Kata Kunci:

BliBli.com; Pemasaran Digital; Promosi; E-Commerce

\section{ABSTRACT}

The digital age has led to the emergence of many companies such as E-commerce, which in the marketing process, not only do marketing through offline media but also have penetrated online or digital media. BliBli.com promotes its brand in collaboration with the digital agency Content Collision to be able to provide SEO (Search Engine Optimization) that can increase PageRank on Google. The purpose of this research is to find out how the communication strategy is carried out by the Content Collision Agency. The research method used is descriptive qualitative data collection through interviews, observations, and study documents. The results showed that the communication strategy used by the Content Collision Agency in promoting BliBli.com was by managing BliBli's blog to be more interesting. Content contained on the website of articles, Slideshare, infographics, and live reports in the field, given a call to action on each document that has made. The content is SEO friendly, up to date, creative, informative, entertaining, distributed via online media, and accompanied by backlinks such as QR code and action buttons (buy now). This method makes it easier for readers to be able to get products and promotions available on Blibli.com. Readers can also share by clicking the share that serves as an expression to express like 
the article and want to share the information by others or just provide feedback for the content through comments. Reviews of products or services from the brand can increase the number of views and also to increase sales.

Keywords:

BliBli.com; Digital Marketing; Promotion; e-commerce 
Nofrizal, W.A. \& Delliana, S. (2021). Communication Strategy of Content Collision Agency ....

\section{INTRODUCTION}

The digital age has led to the emergence of many companies such as E-commerce, which in the marketing process, not only do marketing through offline media but also have penetrated online or digital media. One way to sell a product in the digital age is to utilize various digital business platforms such as BliBli.com. BliBli.com is one of the online stores in Indonesia that provides the most complete and reliable products. With the slogan "Big Choices, Big Deals," Blibli.com is ready to meet various daily needs. BliBli.com promotes its brand through collaboration with digital agencies in Jakarta, namely Content Collision as an advertising agency that focuses on content creation, PR (Public Relations), and Blog Network through digital media or digital marketing. Digital Marketing, according to Sanjaya and Tarigan (2009, p. 47), is a marketing activity including branding that uses various webbased online media such as blogs, web sites, e-mails, AdWords, or social networking.

Digital marketing is not just talking about internet marketing but can also set strategies to promote a brand. According to Effendy (2011, p. 32), the plan is essentially planning (planning) and management to achieve a goal. Similarly, the communication strategy which is a guide to communication planning (communication management) to achieve the goals set. According to Anwar Arifin (2016, p. 5), a communication strategy that is a strategy is a conditional decision about the actions to be taken to achieve the goals. Communication strategy in a company has an essential role as the Content Collision Agency in helping to provide information to the public by providing accurate information that is easy to understand and understand so that it can produce knowledge and understanding of the organization, company, or product.

Basically, in the digital era, when a consumer wants to need goods or services, the first time they do is look for information about the product or service from the brand. For that, the role of Content Collision can provide the best SEO (Search Engine Optimization) for BliBli.com. The specific purpose of SEO is to be able to place a website address at the top or first page of a search engine based on a particular subject. SEO is an essential digital advertising channel where keywords on search engines will get data, which results in a list of links connected to the weblog's website. A weblog is a dynamic website that contains links and comments from visitors or the owner itself (Sumawung, 2012, p. 1).

On this BliBli weblog, Content Collision can be up to date regularly to be able to increase PageRank on Google. Based on this explanation, this study examines how the Content Collision communication strategy in promoting the Blibli.com brand?

\section{Communication Strategy}

According to Effendy (2011, p. 32), the strategy is essentially planning (planning) and management to achieve a goal. However, to achieve these objectives, the plan does not function as a road map that only shows the direction, but must be able to show how operational tactics. Therefore, the communication strategy is a guide to communication planning (communication management) to achieve the goals set. According to Anwar Arifin (2016, p. 5), a communication strategy that is a 
strategy is the overall conditional decision about the actions to be taken to achieve the goal. Communication strategies must be able to demonstrate how operations have carried out practically, which means that the approach can be different at any time, depending on the situation and conditions. From online web-based shopping platform, the market is rapidly shifting towards mobile shopping. The present study may be replicated in mobile shopping and can be compared with web based shopping platform (Swarnakar et al., 2016, p. 215).

When composing a communication strategy that needs to consider are the communication components and look at the supporting and inhibiting factors in each of these components. These components are a) regarding communication objectives, b) the choice of communication media, c) assessment of the purpose of communication messages, and d) the role of communicators in communication, which includes the attractiveness of the source (source attractiveness) and source credibility (source credibility).

\section{AISAS Communication Model}

Sugiyama and Andree revealed (2011, p. 79) that AISAS or Attention, Interest, Search, Action, and Share is the process of consumers paying attention to products, services, or advertisements and having more focus to these products (attention). These products cause interest in consumers' minds (interest) so that it raises the desire to collect information (search) about the product. Consumers make an overall judgment based on the data collected and information presented by the company, taking into account the comments and opinions of people who have bought and used the product or service. If successful, then it becomes a decision to make a purchase (action). After purchasing, consumers become conveyers of information (word of mouth), by talking to others or by sending comments and shows on the Internet (sharing).

According to Ekman, Endoff, \& Samuelsson (2017, p. 62) in combination with existing literature, reviews the AISAS-model and takes a specific target market and industry in consideration. Furthermore, it is evaluated how the decision-making process is affected if the consumer is exposed to an author's brand or when the consumer has received a recommendation/review. AISAS is a Nonlinear Model, which in this AISAS model does not have to move through each of the five stages, as shown in the following picture:

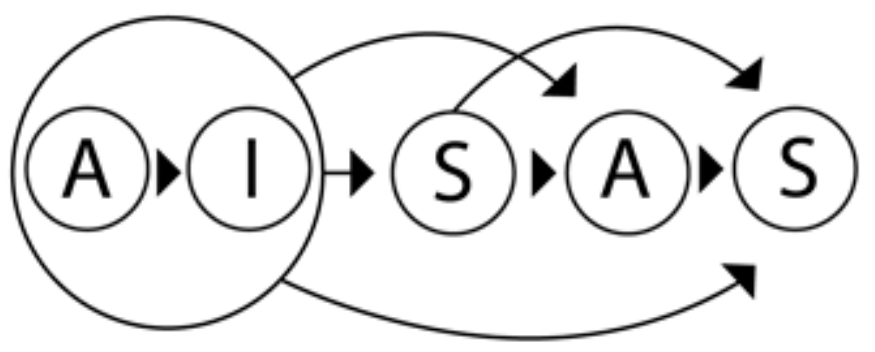

Figure 1: AISAS Model Nonlinear

Source: Sugiyama \& Andree, 2011, (p. 80) 
Nofrizal, W.A. \& Delliana, S. (2021). Communication Strategy of Content Collision Agency ....

Figure 1 shows that in the process, it could have happened one step that might be skipped, or might repeat. For example, a consumer might see a television ad for a similar product, and immediately go to the store to buy it (attention $\rightarrow$ interest $\rightarrow$ action), or he might be so interested in the actress or figure who appears in a television ad. That he only writes about the announcement on his blog (attention $\rightarrow$ interest $\rightarrow$ share). And, maybe in today's world, some consumers only play gadgets to look for information without being driven by advertisements (Sugiyama \& Andree, 2011, p. 80).

\section{RESEARCH METHODS}

With the descriptive case study method, the approach used in this research is qualitative. This qualitative approach is an exploratory approach in which knowledge of the problem is lacking or inexistent (Kriyantono, 2015, p. 46). A descriptive study that aims to describe the strategies used by Content Coallision to promote blibli.com is this type of research. AISAS is a theoretical model that describes the five buying activities processes to affect a marketing campaign. In this study, the marketing program is executed through digital media channels. The research was conducted at the Jakarta office of the Content Collutions Agency and was conducted for six months. In-depth interviews, non-participant observation, and document study were the methods of data collection used. The study data was chosen using a purposeful sampling technique, namely samples taken/determined for a particular purpose or purpose (Pujileksono, 2015, p. 166). Informants in this study are (Chief Editor) and (Account Manager) Content Collision.

In qualitative analysis, all aspects can be perceived differently by each researcher. In a similar analysis, the data collected will not always be used, so it is important to verify the quality and reliability of the data so that there is no misinformation or knowledge coming from the research background (Sugiyono, 2017, pp. 270-277). The test of credibility in this study is related to the question In order to be able to answer the question, to provide Trust in the results of the data obtained in the research presented by the researchers for the results obtained is not as doubtful as the scientific work. Transferability is external validity in qualitative research, this transfer value relates to questions as to the extent to which research results can be applied or used in other situations, the researcher must provide an explanation for a detailed, clear, systematic and reliable report. In order to meet the standards of transferability. Dependability in qualitative research is carried out by conducting an audit of the entire research process, because frontability testing is carried out by auditing the entire research process, if the research process is not carried out but the data are available, then the research is not reliable or reliable. Confirmability in qualitative research is similar to that of testing Dependability, so that testing can be done at the same time. Confirmability testing means testing the results of the research in relation to the process that is being carried out, if the results of the research are a function of the research process that is being carried out, then the research has met the confirmability standard. 


\section{RESULT AND DISCUSSION}

Blibli.com is one of Indonesia's most complete and trusted e-commerce products, with the slogan "Big Choices, Big Deals" Blibli.com is Indonesia's first online mall concept, at that time Blibli.com began attempting to present several different types of products that can be bought and acquired practically through the Blibli.com website. Blibli.com also has multiple supports and partnerships with banks and logistics partners and their merchant partners to work together to manage their blog content on blibli friends, which is beginning to be undertaken to promote Blibli.com's smooth operation. Content Collision creates up-to-date content for 1 month with a target of 90 content per month, the content is an article about a product they want to offer, infographics, slide shares, and field coverage that are then transformed into an article th. Blibli.com trusts the Content Collision Agency to manage their blog content and assist Blibli.com's promotional activities in creating content.

Content Collision is one advertising agency that is trusted to manage blog content from Blibli.com. Content Collision works with in-house writers to create the content, and the writers are scattered everywhere because they are freelance. The blog content itself contains new articles about lifestyle, and there are also slide shares, graphic information, and coverage in the field. Content Collision uses freelancers as content creators to help brands to be able to promote their products by giving reviews in the form of articles or slides to consumers and making content up to date to continue to make the best SEO for the brand. Content articles usually focus on problems in daily life and also provide tips and recommendations for readers. The slide share contains product descriptions that are being offered by Blibli.com and a bit of concise and precise information. For content coverage, the Content Collision fielded the field to look for information and then made new and informative articles.

"For Blibli, we use SEO that is more friendly, for example when they search on Google or open a Belibli blog, we provide an interesting title that searches, but again, don't click a byte because we make sure the contents are not zonked."

Content Collision also uses friendly language throughout the content they create and aims to increase the reader's interest in reading it.

"ow, there are two things about attention, one visual image must be good, we can review it so if there are products. But all do not have to be products and relevant and not all stock photos we also edit the photo. Still, then the photos must also be good and consistent what want to sell. The two interesting titles that are rich have questions that make other people curious in the form of questions, tips or relevance to people, the edges don't click bytes as well, the contents have to be appropriate."

Besides, the agency also provides a check link in each content to be able to direct the reader to buy. This method aims to increase sales that Blibli.com wants to make as the following interview excerpt:

"From each of these content I look for interesting images that match the existing content and also I make a back link on each content, and this is also the goal to be able to lift sales, and I also 
Nofrizal, W.A. \& Delliana, S. (2021). Communication Strategy of Content Collision Agency ....

determine the planning for the content that will be created every month with Tommy and also the experts."

For content creation, Content Collision offers 3 product formats: post/article, infographic/graphic, and video. Whereas for distribution, there are 4 product formats: PR (press release), blog network, blog competition, and social media management. There are two offers for content creation and content distribution, namely performance-based distribution based on the activity of linking content to the audience, and pay per post offers for brands or clients who already have media to disseminate material and only need articles. Content Collision aims to provide effective long-term content to build or manage the brand as much as possible, and clients only pay for the results/results achieved based on the data they have so that the budget/cost is invest following the results obtained. The content distribution also uses liberal media so that the coverage or coverage to a broad audience. The intended media is online media, printed media, radio, and television, while for the use of blog networks, Content Collision has a reach of more than 100 blogger influencers.

"We use communication strategies in online media. We help blogging and social media, especially blogging, what items are import when we write about these items, and we place them on the blog. We give backlinks, so that when other people are interested in reading then want to We have already put backlinks there so other people are easy to buy. Slowly the button has a button "buy now" so other people can immediately buy, then slowly we also play on Instagram stories, but we still focus on creating content."

The strategy is essentially planning (planning) and managing to achieve a goal. In the context of the Content Collision communication strategy, the communication strategy relates to what is in the planning process of each content creation process, where Content Collision makes a plan for its Blibli.com clients, Blibli.com's Content Collision is trusted to manage their blog content. Contains articles, slide shares, graphics info, as well as live reports in the field that will later be published in interesting articles, Content Collision is targeted by Blibli.com on a monthly basis with a target of 90 content per month. Communication components and supporting and inhibiting factors for each of the first components of the communication objectives, Content Collision for each content creation is always varied and differentiates between readers so that the content objective is always correct. The second choice of communication media, Content Collision, is engaged in online content and creates blog content that will definitely be published online, this method is very effective and also cheap compared to other media, and this media is classified as a medium that is quite effective today. The third is the assessment of the message objectives, the Content Collision, which is responsible for providing the reader with a message containing variations, such as product information, product recommendations, and even the final trick tips, where the reader is never bored of reading it because the language is very friendly. Content Collision, which acts as a communicator, always provides information every day, not only 1 information, but up to 3 pieces of information per day, making it free for readers to choose what information they can read. Content Collision also has its own way of writing. The information that he 
uses in this manner will include the appeal and opinion of the readers about the information that the readers have already received.

According to Anwar Arifin (2016, p. 5), a communication strategy that is a strategy is the overall conditional decision about the actions to be taken to achieve the goal. The communication strategy must be able to show how practically the operation must carried out in the sense of the word that the approach can differ at any time, depending on the situation and conditions. Based on the results of the research note that Content Collision, which acts as a communicator, always provides information every day, not only one report but can be up to 3 information every day, which makes the readers free to choose what info can yes read. Content Collision also has its way in every writing that he uses that way can provide the appeal and opinions of readers about the information that has been obtained by its readers.

As stated by Rangkuti (2009, p. 50), the promotion seeks to attract the attention of consumers through information provided to consumers to notify the existence of a company's new products. And advertising is also an activity of the company, continually reminding it so that consumers will want to try and buy company products. Collision content acts as an information provider in the form of material that is kept up to date to its readers, containing exciting and inspirational articles about existing products from Blibli.com. Content Collision always gives a call to action in every section they make, and it aims to increase sales in Blibli.com.

The purpose of the Call to action is when the reader is interested in the content that is create will surely give a sense of ownership of the product. Content Collision always provides a backlink to direct the reader to the product in question, and this method is sufficient enough to be able to increase purchases. However, from promotions conducted by Content Collision, there is a lack in terms of analytics. This analytic plays an essential role in determining the level of advertising going forward as it can determine the segmentation of its readers. Therefore, these deficiencies do not originate from Content Collision but from Blibli.com, which only provides data analytics in the form of the number of views only.

Content Collision makes messages or informative content needed by potential buyers; the content created by Content Collision is persuasive and also has friendly language so that readers are very comfortable and refer to the purchase. According to Jaiz (2014, p. 58) criteria for good advertising are: the message was design to meet the needs of a predetermined audience, has specific goals, and is placed in the media, Has a creative concept in reaching audiences, Using appropriate execution techniques. Content Collision technique in every content creation is; first, the message has made to meet the needs of the audience, so according to the explanation Content Collision always creates informative content that is intended by each reader. The content varies among each group of young people, people elderly and who have certain professions, the use of language that is very important that must be considered by them. They use friendly language so that the readers feel comfortable and also do not get bored quickly. 
Nofrizal, W.A. \& Delliana, S. (2021). Communication Strategy of Content Collision Agency ....

Secondly, having a creative concept in reaching audiences, the intended innovative idea is from creating the content, Content Collision not only makes an article but also creates slide share and graphic info so that the content they create is more varied. Each material can reach all audiences because the media they use uses online media so that everyone can reach it and depend on the needs of each reader. Third, using the right execution technique from this execution technique Content Collision always provides the best SEO, SEO is not just a search engine on Google. Still, SEO is also a long-term investment, that's what Content Collision relies on, they don't use paid advertising but use organic ads that do not pass up payment for promotion, this method is quite powerful. It can reduce the cost is very small.

\section{Analysis of AISAS Communication Model}

In interacting with employees, communication is needed for businesses, which is aimed at receiving the desired feedback or communicating a message to achieve a company's goals (Julianti \& Delliana, 2020, p. 214). This is a process that must be done in this communication strategy before a plan for the future is executed or determined. Caroline Winanta, Chief Editor of Blibli.com, also stated how important a communication strategy is in this planning process to be able to accomplish certain goals of each company. Caroline Winata, Chief Editor, said that the importance of a communication strategy is that good planning can be produced and that the content that will be produced in the future can also be determined. The Account Menager, Sis Tommy Prayoga, conveyed the same thing.

The AISAS model is short for Attention, Interest, Search, Action, and Share (Sugiyama \& Andree, 2011, p. 79). The concept of AISAS is a reference in planning to make a communication strategy.

1. Attention (attention) here has focused on the readers of the content created by Content Collision, the extent to which consumers are interested in content created by Content Collision, because of that the results of data that have been obtained by Content Collison use SEO that is more friendly. And they also use the right visual image to be able to attract their readers, which is always maintained by Content Collision is the content itself that gives an attractive appearance. Still, the content is also of high quality.

2. Interest (Interest) here refers to the reader of any content that Content Collision creates. Content Collision to be able to attract the attention of readers is to use engaging titles and visuals, and they also manage the time where many people can read the content by using more friendly language.

3. Search (Search) here Content Collision is looking for a problem that may be experienced by many people, from these problems they create content that directs from the problem, then applied to a keyword that can type and searched for many people, this method aims to make it easier for readers to get information 
4. Action (Action) is directed at the reader's; from all the content that has been created, Content Collision always convinces readers of every information they provide, therefore in every material, they make such as articles, slide shares, graphic info and also live reports. They always offer backlink features such as QR code and action button (buy now), this method makes it easier for readers to be able to get products and also promotions available on Blibli.com

The Share component has the aim that readers who like the article want to share the information with others or simply provide feedback on the content by adding comments. This component has a weakness because Blibli.com uses filters in each of its articles so that the Content Collision can not measure the level of Share made by the readersi

\section{CONCLUSION AND RECOMMENDATION}

The plan for contact carried out by Material Collision for Manage their Blibli.com customers to produce the content Interesting and insightful blog material viz for their customers. The technique they use, Blibli.com, is very successful and efficient. In terms of the content they would produce, where the Content Collision makes a good plan, This information is packaged in an enticing manner with a visual image and the use of friendly language so that readers do not get bored easily from their content aims to be able to provide different information required by readers. From each content such as posts, graphic sharing slides and even live reports are bundled into information required by the readers, from each content they always produce guides readers to make purchases, so Content Collision always offers a backlink to every content they read, aiming to raise Blibli.com revenue.

The communication strategy undertaken by Content Collision in promoting BliBli.com is by managing BliBli blogs to make it more interesting. Website content derived from articles, slide shares, graphic info, and also live reports in the field was also give a call to action in every section created. The content is SEO friendly, up to date, creative, informative, entertaining, distributed via online media, and accompanied by backlinks such as QR code and action buttons (buy now). This method makes it easier for readers to be able to get products and promotions available on Blibli.com. Readers can also share by clicking the share that serves as an expression to express like the article and want to share the information by others or just provide feedback for the content through comments. Reviews of products or services from the brand can increase the number of views and also to increase sales. 


\section{REFERENCES}

Arifin, A. (2016). Ilmu Komunikasi: Sebuah Pengantar Ringkas. Rajawali Pers.

Effendy, O. (2011). Ilmu Komunikasi. Rosda.

Ekman, L., Endoff, E., \& Samuelsson, E. (2017). Books, Brands and Buzz: The influence of the author's brand andrecommendations and reviews when generationY, in Sweden, selects a book. Jönköping University. http://www.diva-portal.org/smash/get/diva2:1105769/FULLTEXT01.pdf

Jaiz, M. (2014). Dasar-Dasar Periklanan. Graha Ilmu.

Julianti, I., \& Delliana, S. (2020). Rebel Together Sebagai Strategi Komunikasi Pemasaran Digital Madformakeup Di Tengah Pandemi COVID-19. Communicatus: Jurnal Ilmu Komunikasi, 4(2), 207-228. https://doi.org/https://doi.org/10.15575/cjik.v4i2.9686

Kriyantono, R. (2015). Teknik Riset Komunikasi. Kencana Prenada Media Group.

Pujileksono, S. (2015). Metode Penelitian Komunikasi Kualitatif. Intrans.

Rangkuti, F. (2009). Strategi Promosi yang Kreatif dan Analisis Kasus IMC. Gramedia Pustaka Utama.

Sanjaya, R., \& Tarigan, J. (2009). Creative Digital Marketing. Elex Media Komputindo.

Sugiyama, K., \& Andree, T. (2011). The Dentsu Way. Dentsu Inc.

Sugiyono. (2017). Metode Penelitian Kualitatif. Alfabeta.

Sumawung, T. (2012). Menulis di Blog Bisa Bikin Kaya Menciptakan Ladang Bisnis Online. Indeks.

Swarnakar, P., Kumar, A., \& Kumar, S. (2016). Why generation Y prefers online shopping: a study of young customers of India. International Journal of Business Forecasting and Marketing Intelligence, 2(3), 215-232. 